\title{
Motivating
}

Hotel

Although motivation must come from within, outside incentives can

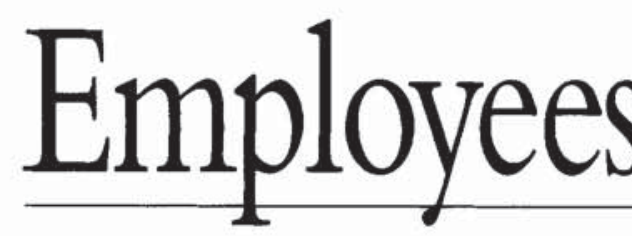

Beyond the Carrot

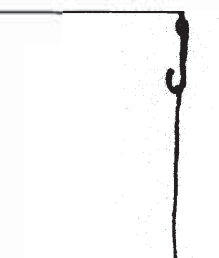

complement those desires.

encourage employees to do a good job. Managers who know what

their employees want can design the work environment to by Tony Simons

and Cathy A. Enz

\section{and the Stick}


into making mistakes while trying to motivate employees. For example, hotels sometimes offer incentives that cost more than they are worth to employees. Employee-of-the-month plaques may be a productive incentive for one department, while in another they may only breed competition or cynicism. Managers cannot force their employees to be motivated, but, if they know what their employees want from work, they can create a coordinated work environment, including coaching, skill development, and rewards, that helps employees motivate themselves.

Motivation is the force that impels people to choose a particular job, to stay with that job, and to try hard. Early approaches to motivation focused on different human needs, including the need for food and shelter, the need for social contact, and the need for creative expression. Such approaches suggest that the tension of an unsatisfied need provides motivation, as people exert effort in the hope that they will satisfy that need. Other approaches to motivation, however, have paid increasing attention to volition; that is, to rational choice processes and to long-term, goal-directed activities. ${ }^{1}$ Recent theories consider that employees make choices based on the results they value, the methods they see as realistic, their long-term goals, and their sense of justice and fairness. Humans are not simply need-based creatures-we interpret work situations based on the context of our lives, our perceived likelihood of success, our cultural values, and the level of satisfaction that we have already achieved.

\footnotetext{
${ }^{1}$ See: Frank Landy and Wendy Becker, "Motivation Theory Reconsidered," Research in Organizational Behavior, Vol. 9 (1987), pp. 1-39; and Ruth Kanfer, "Motivation Theory and Industrial/Organizational Psychology," in

Handbook of Industrial and Organizational Psychology, second edition, ed. M.D. Dunnette,Vol. 1 (Palo Alto: Consulting Psychologists Press, 1990), pp. 75-170.
}

To illustrate this complexity, imagine attempting to get various hotel employees to attend an optional meeting. Tell the general manager that you will give her a free lunch if she attends and you are unlikely to make much headway, but tell her she might learn a few new time-management skills and you might gain her interest. On the other hand, mention new timemanagement skills to the folks at the loading dock and they are likely to laugh, but offer them a free lunch and you might get their attention. This example is exaggerated, but the fact remains that different payoffs are meaningful to different people. Efficient management entails linking meaningful rewards to the level and direction of effort you seek. The question then becomes, "What rewards are meaningful to which people?"

The amount of effort an employee expends toward accomplishing the hotel's goals depends on whether the employee believes that this effort will lead to the satisfaction of his or her own needs and desires. When a need or desire is unsatisfied, a person experiences tension that drives her or him to satisfy the need. People work hard to satisfy their needs and desires, and in this way they reduce their tension. ${ }^{2}$ From this straightforward approach to motivating employees, the key to facilitating motivation lies with managers' accurately understanding what their employees want from their work. Using that knowledge, a manager can more effectively channel employee effort toward organizational goals.

When Kenneth Kovach examined studies carried out between 1946 and 1986, in which thousands of industrial employees were asked to rank ten job-reward factors, he

${ }^{2}$ Abraham Maslow, Motivation and Personality (New York: Harper, 1954). found that employees consistently preferred the rewards of interesting work and appreciation over job security or good wages. These 40 years of studies shaped the belief held by many motivational programs that money doesn't matter. He also found that age and income level made a significant difference in workers' reward preferences. ${ }^{3} \mathrm{~A}$ study of 225 employees at seven Caribbean hotels found that employees ranked good wages and good working conditions as the first and second most preferred rewards. This study also repeated an earlier finding that employee age influences reward preference. ${ }^{4} \mathrm{~A}$ study of Las Vegas casino dealers found that the highest ranked rewards were good wages and job security. ${ }^{5}$

The idea that employees may prefer interesting work over good wages is intriguing, but the early studies were based on workers in manufacturing industries. It seems likely that hospitality workers' preferences would differ from those of manufacturing workers in important ways. The Caribbean study revealed a possible gap between serviceworker motivations and those of industrial employees, but it focused on employees in an underdeveloped economy. Caribbean hospitality workers may have fewer employment alternatives than would North American hospitality workers and they have a different cultural background, which might invalidate the study's applicability to a North

\footnotetext{
${ }^{3}$ Kenneth Kovach, "What Motivates Employees? Workers and Supervisors Give Different Answers," Business Horizons, Sept.-Oct. 1987, pp. 58-65.

${ }^{4}$ Kwame Charles and Lincoln Marshall, "Motivational Preferences of Caribbean Hotel Workers: An Exploratory Study," International Journal of Contemporary Hospitality Management, Vol. 4, No. 3 (1992), pp. 25-29.

${ }^{5}$ Richard Darder, "Six Steps to Creating a Positive Motivational Working Environment," International Gaming and Wagering Business, Vol. 15 (March 1994), pp. 17-18.
} 


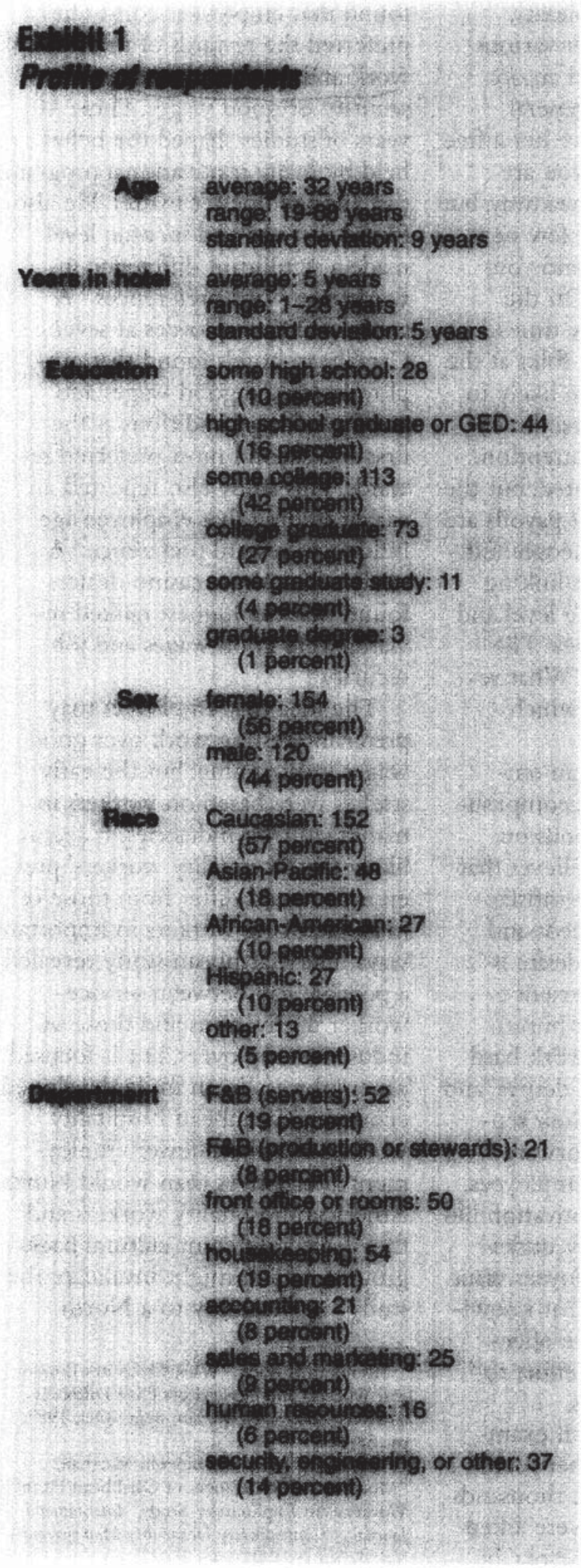

American setting. The study of casino dealers examined workers in a single job within a particular hospitality-industry niche. This level of focus said little about employees in other departments, let alone other settings. The present survey, on the other hand, looks at a representative crosssection of hotel employees throughout the United States and Canada. Furthermore, we specifically ask the question of whether employees in different departments within a hotel are motivated by different rewards.

Information is the key to effective motivation management. To gather this motivation information, we recently conducted a survey that asked employees in 12 U.S. and Canadian hotels what they want from work. This article reports what we found and addresses the following questions:

-What motivates hotel workers?

- Do hotel workers want different things from their jobs and employers than do workers in other industries?

- Are men and women motivated by different job factors?

- Are workers of dif- ferent ages motivated by different job factors?

- Are workers in different departments motivated by different job factors?

-What can a manager do with this information?

\section{The Study Method}

To learn what hotel employees want from work, we asked them to rank ten work factors. To understand how hotel workers might differ in motivation from other workers, we applied the set of work factors that were used in the studies examined by Kovach. We provided the hotel workers with the following list of ten work-related factors:

- good wages,

- tactful discipline,

- job security,

- interesting work,

- feeling of being "in on things,"

- sympathetic help with personal problems,

- opportunities for advancement and development,

- good working conditions,

- personal loyalty to employees, and

- appreciation for accomplishments.

We asked workers to rank the ten factors, from " $1=$ what you want most from your job or organization" to " $10=$ what you want least from your job or organization." Only one factor was permitted to be ranked number one, number two, etc.

A total of 278 employees from twelve different hotels located in the United States and Canada participated in our study. Employees from the hotels voluntarily participated and were representative of the various departments in each hotel. During a six-month period in 1993, two research associates administered the surveys on-site at the 12 hotels. The typical employee surveyed was a full-time employee, 32 years old, who had worked in the hotel for 
H U MAN RESOURCES

five years. Many of the respondents (42 percent) had attended some college, 55 percent of the respondents were white, and 56 percent were women. A profile of the responding employees is provided in Exhibit 1.

\section{General Results}

Overall, hotel employees reported that the three things they most whted from their employers were: (1) good wages, (2) Job security, and (3) opportunities for advancement and development. These results may suggest that high levels of effort can be bought by above-average pay scales. It is true that managers usually face constraints on the salary levels they can offer. It is also true that pay raises often lose their ability to motivate as employees come to feel that they "deserve" their increased levels of fixed pay. Variable pay, where bonuses are linked to specific, measurable performance outcomes (e.g., guestsatisfaction scores), represents a significant motivational opportunity. ${ }^{6}$ In addition, this survey suggests that other employee rewards are valued as well. For example, a promise of job security is something employees want enough to strive for, and a chance at promotion is highly valued by most employees.

Good working conditions, ranked number four by the respondents, is another high-potential motivator. The overuse of threats or reprimands may serve as a strong force against motivation. Hostile and distrusting supervisors can dramatically shape employees' working conditions, and, for many employees, can diminish motivation levels. Note that the friendliness involved in setting up good working conditions is distinct from sympathetic personal help, which was ranked last

\footnotetext{
${ }^{6}$ For another viewpoint, see the guest editorial in this issue of the Cornell Quarterly, p. 80.
}

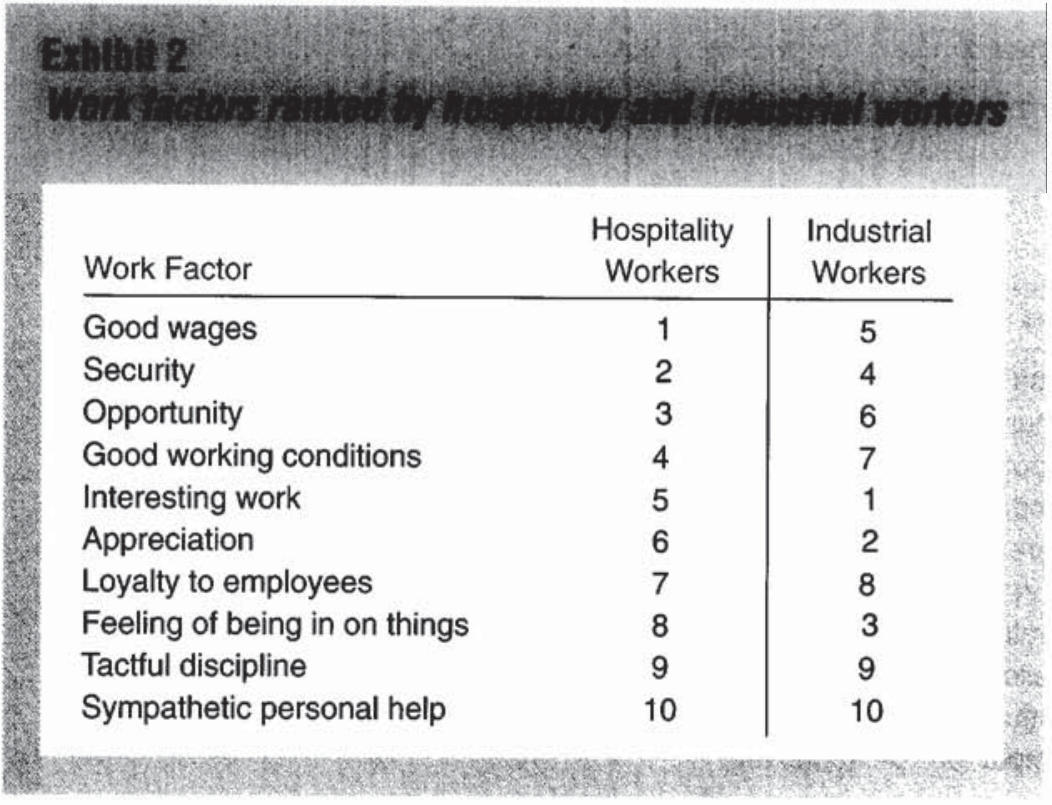

by the hospitality employees. The employees in our study did not want their bosses to be their parents, their buddies, or their psychotherapistswhat they wanted were good working conditions, which might include a safe and clean work environment in which good relationships prevail.

As shown in Exhibit 2, the desires described by hotel workers in our study differ markedly from those described in earlier studies of workers in manufacturing industries.

Those earlier studies, conducted over 40 years with industrial workers, surprised many managers. Supervisors expected workers to say that money and security were the most critical factors that employers could provide, but money and security did not rank among the topthree rewards in studies conducted during that time period. Instead, the top-three reported desires of 1,000 industrial employees were: (1) interesting work, (2) full appreciation of work done, and (3) feeling of being "in on things." "

All of those earlier studies show that industrial workers placed these

\footnotetext{
${ }^{7}$ Kovach, 1987.
} 


\begin{tabular}{lcc|cc} 
& & \multicolumn{3}{c}{ Industrial } \\
& \multicolumn{2}{c}{ Hospitality } & \multicolumn{2}{c}{ Workers } \\
\hline & \multicolumn{2}{c|}{ Workers } & \multicolumn{2}{c}{. } \\
& $<30$ & $30+$ & $<30$ & $30+$ \\
\hline Work Factor & 1 & 1 & 1 & 5.5 \\
\hline Good wages & 6 & 2 & 2 & 4 \\
Security & 2 & 4 & 3 & 8 \\
Opportunity & 4 & 3 & 7 & 5.5 \\
Good working conditions & 3 & 5 & 4 & 1 \\
Interesting work & 5 & 6 & 5 & 2 \\
Appreciation & 8 & 7 & 9 & 7 \\
Loyalty to employees & 7 & 9 & 6 & 3 \\
Feeling of being in on things & 9 & 8 & 8 & 10 \\
Tactful discipline & 10 & 10 & 10 & 9 \\
Sympathetic personal help & & &
\end{tabular}

Note: Rankings for industrial workers over age 30 were computed by ranking numeric averages for the age groups $31-40,41-50$, and over 50 . Due to uncertainty about the number of respondents in each category, this combination of scores results only in an approximation. intangible factors ahead of good wages and job security as things they wanted from their jobs. This surprising outcome makes sense given that factory jobs tend to offer high wages relative to worker skill levels. Those studies suggest that - for factory managers - the development of interesting jobs represents the motivational key to "happy, productive employees who come to work on time and don't quit." 8

Hotel workers differed substantially from industrial workers in the rankings they ascribed to different job factors. This difference indicates the need for different managerial strategies for motivating hotel workers, relative to those used for industrial workers. Hotel employees ranked good wages first, which may be a result of the relatively low wages of service-sector jobs.

Douglas MacGregor, an early management theorist, once said, "Man does not live by bread alone, except where there is little bread." It is likely that the top-three ranked desires-wages, security, and opportunity-represent frustrations experienced by hotel workers. Hotels that create ways for employees to make more money and assume permanent jobs through high performance may be able to improve workers' motivation and productivity.

\section{Motivation for Different Age Groups}

Are the differences between the responses of hotel workers and other workers based wholly on hotel workers' frustration? A further explanation can be drawn by comparing young hospitality employees to those in manufacturing industries. Industrial workers were, on average, approximately 40 years old, while the hotel workers we surveyed were, on average, about 32 years old.

\footnotetext{
${ }^{8}$ Kovach, p. 58.

'Saul Gellerman, Motivation in the Real World (New York: Penguin, 1992), p. 154.
} 
When you examine workers under 30 years of age in industrial settings, their profile of desires is fairly similar to that of hospitality employees and of young hospitality employees in particular. Exhibit 3 compares young workers and old workers in hospitality versus manufacturing industries. The importance ratings made by young workers in hotels and in industrial settings are almost identical-both rank good wages and opportunity for advancement as most important, and both consider their want for interesting work as closely following the other two.

There is a notable difference, however, between the two groups in their attitudes toward job security. Young manufacturing employees ranked security as second in importance only to wages, while young hotel employees ranked it as a relatively low priority.Young hotel workers might rank job security low on their list of desires simply because they do not consider it to be a reasonable expectation on their part. In addition, job-hopping is common in the hospitality industry. The fact that hospitality workers expect to move around could explain why they do not value job security. High turnover rates and low priority assigned to the "job security" factor seem to be related, but the question of causality remains unclear.

Workers over age 30 in the hotel setting offered very different rankings than did the same age group of workers in industrial settings. Older hotel workers ranked good wages, security, and good working conditions as first, second, and third. Older industrial workers emphasized interesting work, appreciation, and a feeling of being "in on things." This difference might reflect components that workers feel are often lacking in these different work environments. Due to the repetitive nature of manufacturing processes, along with the anonymity of the production line, industrial workers might primarily want relief from boredom and appreciation or personal recognition. Due in part to longtime unionization and to the hierarchical structure of industrial companies, older industrial workers might feel relatively satisfied on the issues of wages and job security. However, hotels typically do not pay older workers much more than younger workers-especially when those older workers remain in nonsupervisory jobs, such as room attendant. Thus, hotel workers seem to feel underpaid, and so they rank high wages as a high priority.

The hospitality industry generally offers some employees a sense of appreciated work through contact with pleased customers. For this reason, hotel employees of all ages seemed to feel that appreciation was relatively not a major lack, hence not a high-ranking desire, It is also possible that the very low wages. overwhelm their reward rankings-c employees might feel unappreciated. but money is a more pressing need. Older industrial workers, especially (we imagine) those who have reached a plateau in their career progression, do not have customer contact as a source of appreciation and may consequently lack a feeling of appreciation. Thus, appreciation has powerful motivational potential for factory management, but has less potential for hotel management.

The differences in the desires and needs of old versus young hospitality workers becomes important as the age of the available workforce rises. Older hospitality workers showed some real differences from younger hospitality workers. While both groups ranked good wages as the single most important job factor, younger employees reported opportunities for development and interesting work as the second and third mostwanted job factors. In contrast, 


\begin{tabular}{|c|c|c|c|c|c|c|c|}
\hline Work Factor & $\begin{array}{c}\text { F\&B } \\
\text { Servers }\end{array}$ & $\begin{array}{l}\text { Rooms, } \\
\text { Front desk }\end{array}$ & $\begin{array}{l}\text { House- } \\
\text { keeping }\end{array}$ & $\begin{array}{c}\text { Accounting, } \\
\text { Control }\end{array}$ & $\begin{array}{l}\text { Sales, } \\
\text { Marketing }\end{array}$ & $\begin{array}{c}\text { Back of } \\
\text { House F\&B }\end{array}$ & $\begin{array}{c}\text { Human } \\
\text { Resources }\end{array}$ \\
\hline Good wages & 1 & 1 & 2 & 1 & 2 & 1 & 3 \\
\hline Security & 3 & 4 & 1 & 4.5 & 4 & 5 & 6 \\
\hline Opportunity & 2 & 2 & 5 & 2 & 1 & 4 & 1 \\
\hline Good working conditions & 4 & 5.5 & 3 & 4.5 & 5 & 2 & 4 \\
\hline Interesting work & 6 & 5.5 & 4 & 3 & 3 & 3 & 2 \\
\hline Appreciation & 5 & 3 & 6 & 6 & 6 & 6 & 5 \\
\hline Loyalty to employees & 7 & 7 & 7 & 8 & 8 & 7 & 7 \\
\hline Feeling of being in on things & 9 & 8 & 8 & 7 & 7 & 8 & 8 \\
\hline Tactful discipline & 8 & 9 & 9 & 9 & 9 & 9 & 9 \\
\hline Sympathetic personal help & 10 & 10 & 10 & 10 & 10 & 10 & 10 \\
\hline
\end{tabular}

employees over age 30 reported job security and working conditions as the second and third mostimportant job factors. This difference says that older workers want different things from their jobs than do younger workers. They have different needs and different aspirations. It suggests that managers who are adept at motivating their employees will provide different incentives for their older workers than for their younger ones. A chance to rotate through departments or to be considered for promotion may be an excellent motivator for young hopefuls, but as people age they tend to want a comfortable and pleasant place to work. Younger workers may accept uncertain employment conditions if they see advancement potential. Older workers are likely to find job uncertainty stressful, as security may be one of their main reasons for working at all. The overall pattern suggests that managers should be sensitive to the different needs of different age groups of workers if they are to motivate effectively.

\section{Motivation by Gender}

Are men and women motivated differently? The men and women in our study reported almost identical rankings for the ten job factors, hence this study does not show any real differences in the motivational profiles generated by male and female hotel workers. We can conclude that men and women may require similar, not different, treatment for optimal motivation.

\section{Motivation by Department}

Are workers in different departments motivated by different job factors? Our study says yes. The adept manager should take these differences into account when considering what kinds of incentives and rewards to offer for high performance. Many skilled managers are aware of these differences; however, only a few managers will then take the step of tailoring incentive systems to the departmental differences they perceive.

Motivational profiles for $\mathrm{F} \& \mathrm{~B}$ servers, front-office, housekeeping, accounting, sales and marketing, 
back-of-the-house F\&B, and human-resources employees are shown in Exhibit 4. The top-three job factors for F\&B servers were good wages, developmental opportunities, and job security. Front-office workers gave similar emphasis to wages and opportunity, but placed appreciation in the third spot, followed by job security. While both servers and front-office workers face high volumes of customer contact and emotionally trying situations, servers receive acknowledgment in the form of tips while front-office workers do not. A program of customer-comment cards, perhaps linked to a system of rewards, might provide a greater sense of appreciation for frontoffice employees and thus serve as a potent motivator.

Accounting staff show a similar profile to $\mathrm{F} \& \mathrm{~B}$ and front-office workers, but interesting work is ranked third. This emphasis makes sense in light of those employees' required training and the nature of their work. The sales and marketing staff looked a lot like the accountants, except for the fact that opportunities for advancement were reported as first in importance, edging out wages as the first priority. This pattern may simply suggest that sales and marketing are better compensated and that this need has been diminished. Human-resources workers placed opportunity and interesting work in the number one and two spots, with wages ranked third. While opportunities for advancement ranked among the top three factors for all departments except for back-of-the-house F\&B and housekeeping, they were ranked first by human-resources and sales and marketing employees. This reported importance should be kept in mind as companies trim middle-management layers to optimize corporate efficiency. The absence of those middle layers repre- sents a decrease in promotion opportunity and thus a decrease in a potentially crucial motivating factor for marketing and human-resources personnel.

Employees in the housekeeping area and in back-of-the-house F\&B showed very different profiles from the others, although good wages were still important. For housekeeping employees, however, money was second to job security, and their third priority was working conditions. Housekeeping staff did not take great stock in advancement opportunities, and focused instead on a secure job with good working conditions. For back-ofthe-house F\&B employees, good wages ranked first, followed by good working conditions and interesting work. While young management hopefuls may be willing to tolerate difficult conditions, long hours, and yelling bosses, those same job characteristics might attack the very core of an older, less promotion-seeking room attendant or steward. Workers in these two departments seem to be motivated differently than those in other departments. They might view promotion as highly unlikely, and so focus on having a well-paying, reasonably pleasant, and secure job. A reward system that offers improvements in these job factors could be an extremely potent motivational tool for these groups of employees.

Related to the issue of roomattendants' or stewards' work environment is the scorn that people in these jobs often feel from their superiors. Ambitious young managers often have difficulty understanding the job context of older or less ambitious workers. If managers exhibit disdain or a lack of respect for those people, that negative attitude will then decrease employee motivation, both through an unnecessary decrease in the quality of the working conditions and through a diminution of personal loyalty. Many managers would gain practical productivity benefits from a reexamination of their attitudes toward all major employee groups.

\section{What Can You Do?}

When trying to motivate workers, managers often forget that the desire to do the job must come from within the employee and not from the supervisor. The manager can set the stage for motivation to happen, but cannot force motivation to occur. The level of effort and the direction of that effort are set by workers, based on their perceptions of the most rational way to satisfy their personal desires. What managers can do is to take employee desires into account to create an environment where high effort, properly channeled, will give employees some measure of satisfaction. For many hospitality employees, this optimum motivational environment may involve some form of cash incentive and potential for advancement. For others, it will focus on security and good working conditions. In most cases, a positive, respectful work environment has the potential to facilitate employee retention and generally also to set the stage for excellent performance, particularly in back-of-the-house areas. Useful insight can also emerge from considering the age and department affiliation of different employees.

Still, it is essential to recognize that the general patterns explained here might not hold for a given individual. If you really want to facilitate the motivation of a particular individual, we recommend that you ask them what they want, then set up a path for them to satisfy that desire - a path that includes providing your hotel with extraordinary effort and service. ca 